\title{
PENGARUH PENDIDIKAN DAN PEKERJAAN ORANGTUA DENGAN TINGKAT KEPATUHAN ARV PADA ANAK HIV/AIDS
}

\author{
Zainal Munir'1 ${ }^{1}$ Fendi Romadoni ${ }^{2}$ \\ ${ }^{1}$ Fakultas Kesehatan Universitas Nurul Jadid (UNUJA), Probolinggo,Indonesia \\ ${ }^{2}$ Fakultas Kesehatan Universitas Nurul Jadid (UNUJA), Probolinggo,Indonesia \\ Email: zainalmunirnj@gmail.com
}

\begin{abstract}
ABSTRAK
Terapi Antiretroviral (ARV) merupakan sesuatu pengobatan pada HIV/AIDS, tetapi ketidak tahuan mereka akan informasi yang berkaitan dengan terapi antiretroviral (ARV) akan menimbulkan ketidak patuhan konsumsi obat (ARV). Penelitian ini betujuan untuk menganalisis Pengaruh Pendidikan dan pekerjaan orang tua terhadap kepatuhan konsusmsi obat ARV pada anak HIV/AIDS. Desain penelitian yang digunakan kuantitatif dengan pendekatan cross sectional. Metode yang digunakan adalah Survei Analitik dengan pengambilan sampel secara Total Sampling. Penelitian ini hampir dilakukan selama 3 bulan dengan mendapatkan data langsung pada orangtua yang memiliki anak HIV/AIDS. Selanjutnya penelitian yang dilakukan, bahwa tingkat pendidikan dan pekerjaan orangtua memberikan pengaruh signifikat terhadap tingkat kepatuhan anak dalam konsumsi ARV. Analisa data yang digunakan adalah uji Paired Sample T-Test. Kesimpulan dari penelitian ini : Ada pengaruh pendidikan terhadap kepatuhan ARV, dan ada pengaruh pekerjaan terhadap kepatuhan ARV. di RSUD Waluyo Djati Kraksaan Kabupaten Probolinggo.
\end{abstract}

Kata Kunci : Pendidikan, pekerjaan, orang tua, kepatuhan konsumsi ARV, HIV/AIDS.

\section{INFLUENCE EDUCATION AND PARENT'S WORK ON THE COMPLIANCE OF ARV DRUG CONSENT ON HIV / AIDS CHILDREN}

\begin{abstract}
Antiretroviral therapy (ARV) is a treatment of HIV / AIDS, but their ignorance of information related to antiretroviral therapy $(\mathrm{ARV})$ will lead to non-compliance with drug consumption. This study aims to analyze the influence of education and parent's work on adherence to the consent of antiretroviral drugs in HIV / AIDS children. The research design used quantitative with a cross-sectional approach. The method used is the analytic Survey with Sampling in Total Sampling. The data analysis used is the Paired Sample T-Test. Conclusions from this study: There is an effect of education on ARV adherence, and there is an effect of employment on ARV adherence. at RSUD Waluyo Djati Kraksaan Probolinggo District.
\end{abstract}

Keywords: Education, Parent's Work, Antiretroviral adherence, HIV / AIDS. 


\section{A. PENDAhuluan}

HIV adalah (Human Immunodeficiency Virus) sebuah virus yang menyerang/menginfeksi pada sistem kekebalan tubuh manusia dan menyebabkan AIDS (Acquired Immune Deficiency Syndrome). AIDS adalah kumpulan gejala penyakit yang dapat menyerang sistem kekebelan tubuh kita selama lima hingga sepuluh tahun. Menurunnya kekebalan tubuh dalam tubuh manusia dapat mengakibatkan penderita sangat mudah karena berbagai penyakit infeksi yang sering berakibat fatal (Murni, 2015). Masalah HIV/AIDS adalah masalah besar yang sangat mengancam banyak negara di seluruh dunia. UNAIDS, badan WHO yang mengurusi masalah AIDS, memperkirakan jumalah penderita HIV di seluruh dunia adalah 35 juta orang pada saat itu tidak ada negara yang bebas dari penyakit HIV/AIDS. Data tersebut juga menyebutkan sebanyak 2,1 juta orang baru terinfeksi HIV-AIDS. Orang yang meninggal akibat AIDS sepanjang tahun 2013 telah mencapai 1,5 juta orang. Negara Asia dan The Pacific merupakan tertinggi ketiga setelah Sub-Saharan Africa dan Middle East dan North Africa dengan jumlah 4,5 juta orang dengan kematian sebanyak 250.000 orang. (World Health Organization, 2013).

Hasil penelitian dalam bidang infeksi HIV memberi harapan dalam bidang pencegahan dan terapi. Berbagai upaya pencegahan yang sudah dikenal seperti perilaku sehat, penggunaan kondom ,serta pencegahan pemakaian jarum suntik bersama tetap merupakan upaya yang penting, namun pemberian obat anti retriviral (ARV) ternyata mampu menurunkan resiko penlaran secara nyata. Berdasarrkan peneliitian, WHO menetapkan pencapaian pada tahun 2015 yaitu menurunkan infeksi baru HIV pada laki-laki dan perempuan muda sebesar 50\%, menurunkan infeksi baru HIV pada bayi dan anak sebesar $90 \%$, dan menurunkan angka kematian terkait HIV sebesar 50\%. (Setiati, 2014).

HIV/AIDS menyebabkan berbagai krisis secara bersamaan, menyebabkan krisis kesehatan, krisis pembangunan. Dengan kata lain HIV/AIDS penyebabkan krisis mulltidimensi. Sebagai krisis kesehatan, AIDS memerlukan respons dari masyarakat dan memerlukan layanan pengobatan dan perawatan untuk individu yang terinfeksi (Setiati, 2014). Penelitian terhadap faktor-faktor yang berpengaruh terhadap kepatuhan konsusumsi ARV ada tiga faktor yang paling signifikan terhadap kepatuhan pasien HIV/AIDS, dengan faktor pengetahuan pasien menjadi faktor paling dominan, dibandingkan dua faktor lain yaitu tingkat pendidikan dan Beck Deppresion Inventory (Martono, 2013). Ditambah dengan adanya penelitian tentang Hubungan Pendidikan Dan Pekerjaan Dengan Kepatuhan Ibu Hamil Dengan Hiv Dalam Mengkonsumsi Arv. Di dapatkan bahwa ada hubungan yang signifikan antara pendidikan dan pekerjaan dengan kepatuhan kehamilan dengan HIV dalam pengambilan obat antiretroviral (Anasari, 2017).

Anak adalah manusia kecil yang masih butuh orang lain dalam artian orang tua. Orang tua disini mempunyai peranan penting terhadap tanggung jawab kepada anaknya. Dari uiraian tersebut peneliti ingin mengetahui akan kah ada pengaruh pekerjaan dan pendidikan orang tua terhadap kepatuhan komsumsi obat ARV pada anak HIV/AIDS.

\section{B. METODE}

Penelitian ini menggunakan desain survei analitik dengan pendekatan cross sectional dengan jumlah responden 31 Orang. Cross sectional adalah suatu penelitian untuk mempelajari dinamika kolerasi antar faktor-faktor resiko dengan efek, dengan cara pendekatan observasi atau 
pengumpulan data sekaligus pada suatu saat. (Siyoto, 2015).

Instrumen merupakan langkah penting dalam pola prosedur penelitian. Instrumen berfungsi sebagai alat bantu dalam mengumpulkan data yang di perlukan. Bentuk instrumen berkaitan dengan metode pengumpulan data (Siyoto, 2015).
Instrumen yang digunakan pada variabel independen adalah kuesioner dan untuk variabel dependen peneliti menggunkan koesioner dengan tujuan agar peneliti memperoleh data yang sesuai dengan tujuan peneliti. Kuesioner dilakukan dengan cara memberikan pertanyaan-pertanyaan tertuslis kepada respoden untuk dijawab.

\section{HASIL DAN PEMBAHASAN}

\section{Data Umum}

a. Karakteristik Pendidikan Orangtua

Tabel 1. Pendidikan orang tua

\begin{tabular}{ccc}
\hline Tingkat Pendidikan & Frekuensi & Presentase \\
\hline Tidak Sekolah & 7 & 22,6 \\
\hline SD & 15 & 48,4 \\
\hline SMP-SMA & 8 & 25,8 \\
\hline D3-PT & 1 & 3,2 \\
\hline Total & 31 & 100
\end{tabular}

Berdasarkan Tabel 1. diatas dapat diketahui sebagian besar orang tua mempunyai pendidikan tingkat SD sebanyak 15 orang (48.4\%).

b. Karakteristik Pekerjaan Orangtua

Tabel 2. Pekerjaan orang tua

\begin{tabular}{ccc}
\hline Pekerjaan & Frekuensi & Presentase \\
\hline IRT/ tidak bekerja & 5 & 16,1 \\
\hline Buruh & 17 & 54,8 \\
\hline Wiraswasta & 8 & 25,8 \\
\hline PNS & 1 & 3,2 \\
\hline Total & 31 & 100,0
\end{tabular}

Berdasarkan Tabel 2. diatas dapat diketahui sebagian besar orang tua mempunyai tingkat pekerjaan buruh sebanyak 17 orang $(54.8 \%)$.

\section{Data Khusus}

a. Pengaruh pendidikan orang tua terhadap kepatuhan konsumsi ARV

Tabel 4. Distribusi pengaruh pendidikan orang tua terhadap kepatuhan konsumsi ARV

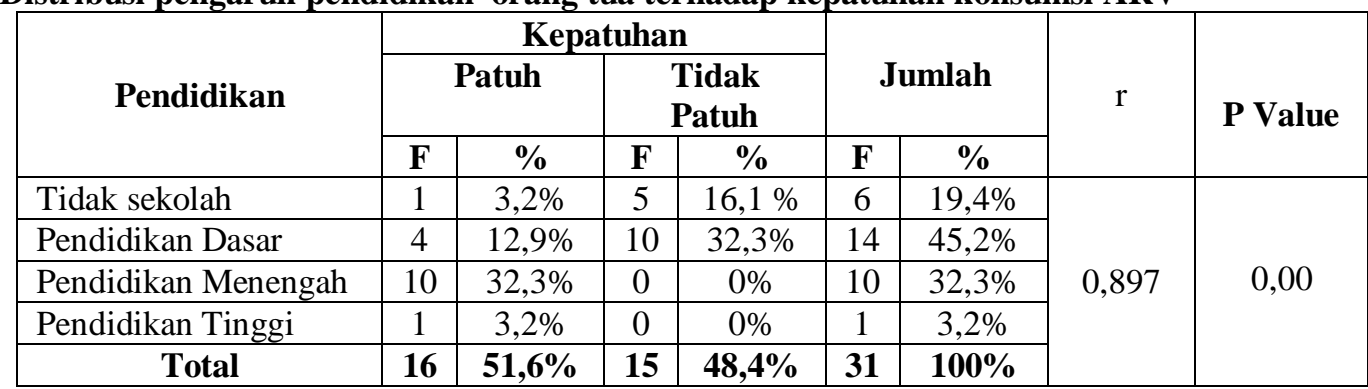

Berdasarkan tabel Tabel 4. hasil Uji Kolerasi Gamma, yaitu tingkat pendidikan dengan kepatuhan di dapatkan P. Value atau Sig ( 2 tailed) = 0,00 Hal itu berarti bahwa probabilitas kurang dari 0.05 yang berarti ada pengaruh yang signifikan pendidikan terhadap kepatuhan konsumsi obat ARV pada anak HIV/AIDS. Jadi bisa disimpulkan semakin tinggi tingkat pendidikan. Maka, tingkat kepatuhan orang terhadap konsumsi ARV semakin baik. 
b. Pengaruh Pekerjaan orang tua terhadap kepatuhan konsumsi ARV

Tabel 5. Distribusi pengaruh pekerjaan orang tua terhadap kepatuhan konsumsi ARV

\begin{tabular}{|c|c|c|c|c|c|c|c|c|}
\hline \multirow{3}{*}{ Pekerjaan } & \multicolumn{4}{|c|}{ Kepatuhan } & \multirow{2}{*}{\multicolumn{2}{|c|}{ Jumlah }} & \multirow{3}{*}{$\mathbf{r}$} & \multirow{3}{*}{ P Value } \\
\hline & \multicolumn{2}{|c|}{ Patuh } & \multicolumn{2}{|c|}{$\begin{array}{l}\text { Tidak } \\
\text { Patuh }\end{array}$} & & & & \\
\hline & $\mathbf{F}$ & $\%$ & $\mathbf{F}$ & $\%$ & $\mathbf{F}$ & $\%$ & & \\
\hline Tidak Bekerja & 0 &, $0 \%$ & 6 & $19,4 \%$ & 6 & $19,4 \%$ & \multirow{5}{*}{0,1} & \multirow{5}{*}{0,00} \\
\hline Buruh & 8 & $48,8 \%$ & 9 & $29,0 \%$ & 17 & $29,0 \%$ & & \\
\hline Wiraswasta & 8 & $29,0 \%$ & 1 &, $0 \%$ & 8 & $29,0 \%$ & & \\
\hline PNS & 7 & $22,6 \%$ & 0 & $3,2 \%$ & 7 & $22,6 \%$ & & \\
\hline Total & 16 & $51,6 \%$ & 15 & $48,4 \%$ & 31 & $100 \%$ & & \\
\hline
\end{tabular}

Berdasarkan tabel Tabel 5. hasil Uji Kolerasi Gamma, yaitu tingkat pekerjaan dengan kepatuhan di dapatkan P. Value atau Sig (2 tailed) $=0,00$ Hal itu berarti bahwa probabilitas kurang dari 0.05 yang berarti ada pengaruh yang signifikan pekerjaan terhadap kepatuhan konsumsi obat ARV pada anak HIV/AIDS. Jadi, semakin baik tingkat pekerjaan orang tua belum memberikan dampak yang signifikat terhadap kepatuhan konsumsi ARV. Tapi, tingkat pekerjaan yang lebih banyak bersama keluarga memberikan pengaruh yang signifikan.

c. Pengaruh pendidikan orang tua terhadap kepatuhan konsumsi ARV

Hasil penelitian yang dilakukan oleh Dwi Anis Sulistiari, pasien dengan diabetes mellitus tipe 2 ada pengaruh Pendidikan terhadap Kepatuhan Pasien Diabetes Mellitus Tipe 2 dalam Melakukan Perawatan Kaki (Sulistiari 2011). Hal tersebut sependapat dengan penelitian oleh arif, arif dalam penelitiannya menyatakan faktorfaktor yang mempengaruhi kepatuhan berobat pasien yang di terapi dengan tamoxiven adalah faktor yang mempengaruhi adalah umur, tingkat pendidikan, pendapatan keluarga, ketersediaan asuransi kesehatan dan pelayanan tenaga medis (Budiman, 2013).

Menurut asumsi peneliti, pengaruh pendidikan orang tua terhadap kepatuhan konsumi obat ARV pada anak HIV/AIDS sangat berpengaruh terhadap kepatuhan konsumsi obat anak HIV. Pendidikan yang didapatkan melalui pendidikan akan berpengaruh terhadap pemahaman orangtua dalam konsep penyakit anak. Maka, semakin tinggi tingkat pendidikan orangtua diharapkan memberikan kontribusi tingkat kepatuhannya konsumsi ARV. Maka, anak dapat terkontrol kepatuhan konsumsi obatnya untuk meningkatkan kesehatannya, mempertahankan hidupnya dan mencegah terjadinya komplikasi. Anak dengan HIV sangat membutuhkan cinta dan kasih sayang orang tua, anak yang masih dalam proses tumbuh kembang, mempunyai kebutuhan yang spesifik, sehingga perlunya pengawasan dari orang tua. Dari penelitian yang telah dilaksanakan, orang tua dengan anak HIV/AIDS di poli VCT RSUD Waluyo Jati Kraksaan pada tingkat pendidikan dan pekerjaan orang tua sangat berpengaruh terhadap kepatuhan konsumsi obat ARV.

d. Pengaruh pekerjaan orang tua terhadap kepatuhan konsumsi ARV

Pengaruh pekerjaan orang tua terhadap kepatuhan konsumi obat ARV pada anak HIV/AIDS sangat berpengaruh terhadap kepatuhan konsumsi obat anak HIV, selain memberikan perhatian kusus terhadap sang anak, orang tua juga berkewajiban untuk memenuhi kebutuhan pokok anaknya untuk terpenuhi dan kepatuhan konsumsi obatnya akan terpenuhi juga untuk kesehatannya, mempertahankan hidupnya dan mencegah terjadinya komlikasi. Anak dengan HIV sangat membutuhkan asupan nutrisi yang cukup untuk memenuhi kebutuhan di dalam tubuhnya, orang tua disini berperan penting terhadap kebutuhan nutrisi anaknya yang masih dalam proses tumbuh kembang. Orang tua dengan tingkat pekerjaan yang tinggi tentunya segala kebutuhan nutrisi anak akan terpenuhi, 
sehingga perlunya pemenuhan nutrisi anak dari orang tua. Dari penelitian yang telah dilaksanakan, orang tua dengan anak HIV/AIDS di poli VCT RSUD. Waluyo jati kraksaan pada tingkat pekerjaan orang tua sangat berpengaruh terhadap kepatuhan konsumsi obat ARV.

\section{SIMPULAN}

Hasil penelitian dapat disimpulkan bahwa ada pengaruh pendidikan dan pekerjaan orang tua terhadap kepatuhan konsumsi obat ARV pada anak HIV/AIDS.

1. Ada pengaruh pendidikan orang tua terhadap kepatuhan konsumsiobat ARV pada anak HIV/AIDS di RSUD Waluyo Djati Kraksaan.

2. Ada pengaruh pekerjaan orang tua terhadap kepatuhan konsumsiobat ARV pada anak HIV/AIDS di RSUD Waluyo Djati Kraksaan.

\section{DAFTAR PUSTAKA}

Murni, N. N. A., Suherni, T., \& Suhartono. (2014). Pengaruh Latihan Relaksasi Guided Imagery And Music (GIM) Pada Kelas Ibu Terhadap Derajat Kecemasan Ibu Hamil Menghadapi Persalinan Pertama, $I(1), 1197-1206$.

Martono, dkk. (2006). Pencegahan dan penanggulangan penyalahgunaan narkoba berbasis sekolah. Jakarta: Balai pustaka.

WHO. (2013). HIV/AIDS menurut WHO.

Setiati S, Alwi I, Sudoyo AW, Stioyohadi B, Syam AF. Buku Ajar ilmu penyakit dalam jilid I.VI. Jakarta : internal Publishing; 2014:1132-53.

Anasari,T. 2017. Hubungan pendidikan dan pekerjaan dengan kepatuhan ibu hamil dengan HIV dalam mengkonsumsi ARV di RSUD Prof Margono Soekarjo Purwokerto. Prosiding seminar nasional dan presentasi hasil-hasil penelitian serta pengabdian masyarakat bidang kesehatan.272.283.

Siyoto, S \& Sodik,A. 2015. Dasar Metodologi Penelitian. Cet.I. Literasi Media: Yogyakarta 